\title{
Microbial Fuel Cells, Related Technologies, and Their Applications
}

\author{
Gene Drendel ${ }^{1}$, Elizabeth R. Mathews ${ }^{1}$, Lucie Semenec ${ }^{1}$ and Ashley E. Franks ${ }^{1,2, *(D)}$ \\ 1 Department of Physiology, Anatomy and Microbiology, La Trobe University, Melbourne, VIC 3086, \\ Australia; 16118761@students.latrobe.edu.au (G.D.); er2mathews@students.latrobe.edu.au (E.R.M.); \\ 17653203@students.latrobe.edu.au (L.S.) \\ 2 Centre for Future Landscapes, La Trobe University, Melbourne, VIC 3086, Australia \\ * Correspondence: a.franks@latrobe.edu.au
}

Received: 31 October 2018; Accepted: 20 November 2018; Published: 25 November 2018

\begin{abstract}
Microbial fuel cells present an emerging technology for utilizing the metabolism of microbes to fuel processes including biofuel, energy production, and the bioremediation of environments. The application and design of microbial fuel cells are of interest to a range of disciplines including engineering, material sciences, and microbiology. In addition, these devices present numerous opportunities to improve sustainable practices in different settings, ranging from industrial to domestic. Current research is continuing to further our understanding of how the engineering, design, and microbial aspects of microbial fuel cell systems impact upon their function. As a result, researchers are continuing to expand the range of processes microbial fuel cells can be used for, as well as the efficiency of those applications.
\end{abstract}

Keywords: microbial fuel cell; sustainability; bioremediation; energy; electricity; biofuel

\section{Introducing Microbial Electrochemical Systems for Bioremediation, Energy and Biofuel Production}

Microbial electrochemical systems (MESs), also commonly referred to as bioelectrochemical systems (BESs), are technologies that harness the metabolic functions of living microorganisms to convert chemical energy stored in organic material to bioelectrical current production or biofuel production [1]. These technologies span the collective fields of microbial electrochemistry, engineering, materials science and environmental science among others. Two major types of MESs are microbial fuel cells (MFCs), which utilise microorganisms to convert organic compounds into electrical power, and microbial electrolysis cells (MECs), which require a net power input for the microbially driven synthesis of biofuels and other commodity chemicals through microbial electrosynthesis (ME) [2-5].

MESs are generally comprised of the same basic components: a working electrode and a counter electrode, contained in separate compartments, which may be separated by a proton exchange membrane (PEM). The anolyte medium of the MES contains organic or inorganic substrates that provide a source of electron donors to the microbes in the anode chamber. In pure culture MESs, anode-respiring bacteria (ARB) oxidise electron donors present in the anolyte medium and pass the electrons to the anode as the final electron acceptor; whereas, in mixed microbial community MESs, the electron donors present as complex organics are often first oxidised by fermentative bacteria. The ARBs may then oxidise the simple organic acid by-products of the fermentation. Electrons donated to the anode by the ARBs then travel to the cathode via a conductive wire connecting the two electrodes. These electrons combine with the protons that have physically relocated from the anode to the cathode via the PEM to form resultant products such as water or biofuels such as methane or ethanol $[1,5]$.

MFCs came to prominence with the discovery of electrochemically active microorganisms (EAMs), microbes with the ability to interact with electrodes [6]. Lovley and Phillips [7] demonstrated that 
some microorganisms could respire by coupling organic carbon oxidation with dissimilatory $\mathrm{Fe}(\mathrm{III})$ reduction, using the iron as the final electron acceptor. The work of Allen and Bennetto [8] found that MFCs produced electricity using various carbohydrate carbon sources and chemical mediators to transfer electrons. Some EAMs were also discovered that were able to generate electricity in MFCs without the need for chemical mediators. One of the earliest examples was Shewanella putrefaciens, an Fe(III)-reducing bacteria, using an electrode as its electron acceptor [9]. EAMs can be classified as electricigens, microbes which are capable of completely oxidising organic compounds to carbon dioxide and donating electrons directly to an electrode [10,11], and electrotrophs, microbes that can accept electrons from electrodes for the reduction of terminal electron acceptors [12]. Marine and aqueous sediments have also been used as a substrate in benthic microbial fuel cells (BMFC) $[13,14]$. Also known as sediment MFCs (SMFC), they generate a small but constant current from microbial processes occurring in the sediment of aqueous environments. BMFCs can be utilised in marine and aqueous environments to power equipment that requires a constant low level power $[2,13,14]$.

MFCs can vary in architecture from single and double-chambered fuel cells to stacked MFCs. Stacked MFCs are a parallel configuration of MFCs which are higher in efficiency than standard two-chamber MFCs [15]. Benthic or sedimentary microbial fuel cells (SMFCs) are another form of MFC where the anode is placed into the aquatic sediments, and the cathode into the overlying water column to generate power [10]. A further extension of MFC technology includes microbial desalination cells (MDCs), which contain two ion exchange membranes between the anode and cathode chambers in MFCs or plant or algal microbial fuel cells (PMFCs), the latter two of which incorporate photosynthetic organisms to enhance power generation [16].

As with MFCs, MECs can also vary in type and architecture. Two main types of cells fall under the banner of MECs: microbial electrolysis cells and microbial electrosynthesis cells [1,4]. One of the first instances of MECs developed for biofuel production was a biochemical fuel cell that utilised glucose fermentation by Clostridium butyricum for the generation of hydrogen [17]. Microbial electrolysis cells require a supplied external voltage in addition to that produced at the anode. These types of cells are often used to generate hydrogen as a biofuel. In microbial electrosynthesis, cell reactions occur at the cathode with carbon dioxide as the carbon source, and electrons are derived from the cathode to synthesise valuable chemicals and biofuels. The main difference in application between MFCs and MECs is that MFCs provide clean renewable energy with the ability to concurrently bio-remediate contaminated environments, while MECs use external energy to microbially synthesise biofuels and other valuable substrates.

MES research is an area that continues to grow not only in power production but also in the field of bioremediation applications and the production of biofuels and commodity chemicals [2,4,18-21]. One particularly effective example of MFCs as a bioremediation tool was their demonstrated ability to remediate uranium-contaminated groundwater in Rifle, Colorado [22]. In this case, graphite electrodes were inserted into the groundwater aquifer at regular intervals with acetate injected as a carbon source for the bacteria [23]. Dissimilatory metal-reducing bacteria (DMRB), selected for by providing acetate as an electron source, reduced soluble uranium (VI) to insoluble uranium (IV) which precipitated onto the electrode, thus enabling its removal from groundwater [22]. With a growing demand for higher power generation, studies have progressed into using domestic sewerage and other wastewaters in an attempt to generate higher power levels $[15,20,24-26]$. However, even when utilising wastewater as a carbon source, MFCs are currently limited in their power production.

\section{The Living Building Blocks of MESs}

\subsection{The Bacteria-Electrode Interface}

Thus far, we have discussed the role that alternative architectures and materials play in influencing MES function. In this section, we will focus on the biological aspect of these systems, describing the complex array of microbial electron transfer mechanisms within electrode biofilms as a means to 
understand how to optimize these mechanisms for optimal MES productivity. Over the past five decades, many patents have been filed, describing inventions in which bacterial metabolic activity is harnessed to enhance MES function [27-30]. In the anode compartment, electroactive microorganisms (EAMs) called electricigens utilize the anode as an extracellular electron acceptor, thereby generating small amounts of current [31,32]. In the cathode compartments of these systems, EAMs called electrotrophs catalyse the production of useful biofuels such as hydrogen $[33,34]$ by utilizing the electrode as an extracellular electron donor.

There are a range of currently known EAMs which are capable of interacting with electrodes. Among the most well characterized electricigens are those belonging to Geobacter and Shewanella genera, including Geobacter sulfurreducens and Shewanella oneidensis $[6,35,36]$. Other known examples of EAMs include those from the genera Pseudomonas [37], Geothrix [38], Clostridium [39], Desulfuromonas [31], Desulfovibrio [40], Desulfobulbus [41] and Enterobacter [42]. Not as many electrotrophs have been identified to date, and these include Geobacter [33,43-45], Clostridium, Moorella [4], Sporomusa [4,46,47]. Given this broad range of EAMs, it is not surprising that they often differ in the types of mechanisms they utilise for extracellular electron transfer (EET).

\subsection{Bacteria-Anode Interactions}

As previously mentioned, electricigens are capable of utilising the anode as a terminal electron acceptor and the currently known mechanisms by which they perform this extracellular electron transfer (EET) include direct EET (DEET) via either cytochromes from the microbe to the electrode, pilin mediated EET (PEET) utilising pili structures or indirect transfer via electron shuttle-mediated EET (SEET) (Figure 1) [36,48].

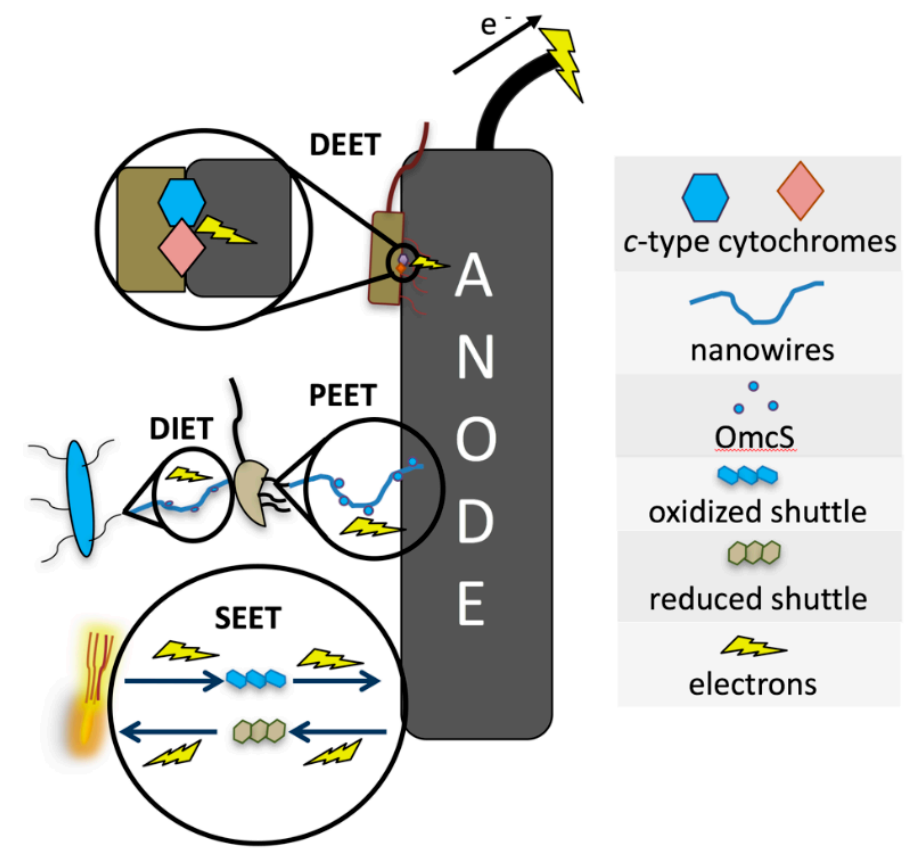

Figure 1. Mechanisms of interaction of electroactive microorganisms (EAMs) with the anode of microbial electrochemical systems (MESs) include direct extracellular electron transfer (DEET) through membrane bound cytochromes, PEET by using electroconductive pili, the use of soluble electron shuttles (SEET), and interactions between different species, directly transferring electrons between one another (DIET).

\subsection{Direct Extracellular Electron Transfer (DEET)}

Microbial communities enriched at anode surfaces placed in the environment are commonly dominated by proteobacteria, of which Geobacter spp. is a member [49]. The direct transfer of 
electrons to electrodes has been most heavily investigated in G. sulfurreducens [6] The direct exchange of electrons from microbes to an electrode is achieved by membrane-bound cytochromes such as OmcZ [50]. G. sulfurreducens has been demonstrated to have a substantial diversity of cytochromes, suggesting the potential for flexibility in cytochrome function, and of these, OmcZ has been the most well characterized cytochrome in the direct transfer of electrons to electrodes in MFCs [6,50-54]. The importance of OmcZ to electron transfer to electrodes and subsequent current generation became apparent after the deletion of OmcZ was observed to decrease the ability to exchange electrons to the anode, while deletions of other cytochromes did not have as significant an effect [51].

\subsection{Pilin-Mediated Extracellular Electron Transfer (PEET)}

G. sulfurreducens is also capable of electron transfer over longer ranges via electroconductive pili $[55,56]$. The presence of OmcS aligned along the length of pili has been suggested as one mechanism increasing conductivity for electron transfer [52]. The use of pili as a conductive electron transfer network throughout $G$. sulfurreducens biofilms has been suggested based on the observation of relatively thick biofilms being electroconductive [56,57]. Furthermore, the conductive nature of G. sulfurreducens pili has been demonstrated through the replacement of its PilA with that from Pseudomonas aeruginosa, resulting in decreased conductivity and the ability to reduce Fe(III) Oxide [58]. The metallic-like conductive nature of pili has, however, been a controversial topic, with differing interpretations of data resulting in different hypotheses [59-63].The alternative hypothesis, known as the super exchange model of electron transfer, has also been proposed, in which electrons are proposed to successively transfer between redox proteins via a "hopping" mechanism [64]. However, this hypothesis is argued to be less suited to current knowledge surrounding biofilm conductivity than the hypothesis of a metallic-like conductivity of pili $[62,64,65]$. Subsequent investigation has further supported the metallic-like conductivity of G. sulfurreducens pili based on the structural arrangement of aromatic amino acids of the pili [60]. More recently, the expression of electroconductive PilA from G. metallireducens by G. sulfurreducens has been found to improve conductivity of pili beyond that of any other EAM currently known [66]. Interestingly, this model for pili conductivity is different to that seen in S. oneidensis, in which it is more likely suggested that electrons hop between redox sites along membrane extensions $[67,68]$

\subsection{Shuttle-Mediated Extracellular Electron Transfer (SEET)}

The production and use of soluble electron shuttles by microorganisms allow the reduction of electrodes without the need for direct contact with them. While electron transfer of Geobacter sulfurreducens to anodes is observed to occur within electroconductive biofilms, the transfer of electrons to anodes by Shewanella oneidensis has been observed to occur via endogenously produced redox shuttles by mainly planktonic S. oneidensis [6]. Flavins produced by S. oneidensis can be reduced by the microbe via c-type cytochromes and subsequently oxidized during interaction with a metal such as $\mathrm{Fe}^{3+}$ or an electrode [69].

\section{Bacteria-Cathode Interactions}

Cathode-associated electrotrophs are capable of utilising the cathode of MESs as an electron donor, consuming the electron flow generated from the initial electron transfer by electricigens [4]. The composition of cathode-associated communities is less well understood than anode communities [70]. Unlike anode-associated communities, cathode-associated communities have been demonstrated to contain a mix of both aerobic and anaerobic microbes, and one study found a dominance of Oceanospirillales, followed by Bacteroidales, within cathode-associated communities [70]. Of the Oceanospirillales, Nitrincola spp. were most prevalent at the cathode, and being aerobic, it has been suggested that an oxygen gradient may influence cathode community structure [70]. Consideration of the microbial community associated with cathodes may be an important consideration for PMFCs, both in regards to how those communities may affect the plant, and how differing conditions of 
PMFCs, including the availability of oxygen and water, may affect microbial community composition and function.

Bacteria-cathode interactions are of particular importance in the synthesis of biocommodities such as biofuels. However, in comparison to bacteria-anode interactions, the mechanisms of cathode interactions and their study are less prevalent. It has been predicted that mechanisms of direct electron transfer, including $c$-type cytochromes, are likely similarly important for cathode reactions as anode reactions (Figure 2); however, operating instead at differing redox potentials [71]. Other mechanisms such as flavins, ferredoxins, rubredoxins, hydrogenase, and formate dehydrogenase have also been investigated for the potential of cathode interaction [72]. The acetogenic EAM Sporomusa ovata has been used to demonstrate the production of acetate and 2-oxobutyrate with up to $86 \%$ of electrons from the cathode appearing in these products [4]. However, further optimisation of the microbial and industrial processes for biofuel and other biocommodity production will be required if these devices are to provide a viable alternative to fossil fuels [73].
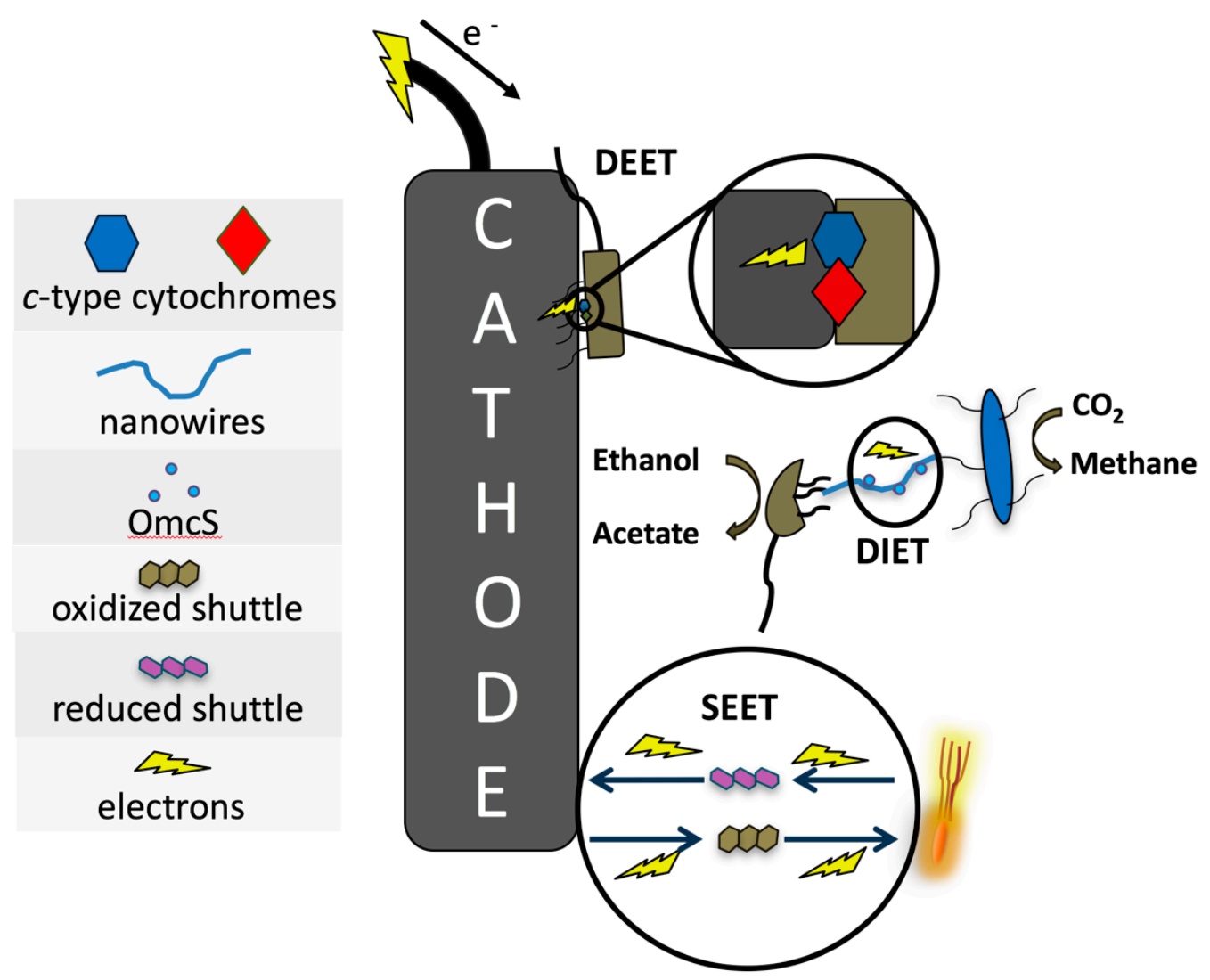

Figure 2. Although less well characterised compared to anode interactions, the potential mechanisms of interaction of electrochemically active microorganisms (EAMs) with the anode of MESs include DEET through membrane bound cytochromes, SEET, and interactions between different species including syntrophic interactions with acetogens or methanogens directly transferring electrons between one another (DIET).

\section{The Electrogenic Biofilm Interface}

Given that mixed community biofilms can form on electrode surfaces, it is important to also consider the EET activities between microbes existing in these electrode biofilms. Bacteria can exchange electrons between one another in an indirect manner via exogenous shuttles such as hydrogen and formate [74,75], or via the more closely associated mechanism of direct interspecies electron transfer (DIET), where electrons can be transferred directly between bacteria [76-79]. The interactions between microbes within electroconductive biofilms may be syntrophic or competitive, and in turn may alter 
the performance of MECs for the production of power or bioremediation $[80,81]$. The syntrophic transfer of electrons in mixed species biofilms allows for microbes that may not individually be capable of oxidising a compound to survive. For example, the growth of G. sulfurreducens and G. metallireducens in the presence of ethanol and fumarate results in the reduction of fumarate by G. sulfurreducens, producing hydrogen which in turn is consumed by G. metallireducens in the metabolism of ethanol $[36,76]$. In the environment, the activity of Geobacter species within methanogenic rice paddy soil has been linked with the potential for syntrophy with methanogens, indicating the potential for use in biogas production [82-84]. Furthermore, by allowing electron transfer between species without close contact, DIET can be enhanced by the presence of conductive materials such as biochar, carbon cloth and granular activated carbon [85-87].

\section{Electrode Materials}

The materials used for electrodes in MESs can be divided into three groups: anode materials, cathode materials and other materials such as fillers and mediators [88]. There are many factors that contribute to what material makes a good electrode, including easy availability, high conductivity, low cost, high surface area, low chemical reactivity and the rate of electron transfer within the MFC, which relates directly to power output [88]. One material that fits all of the above criteria is carbon/graphite, which makes it a popular choice for electrodes.

\subsection{Carbon-Based Electrodes}

Carbon materials can be further separated, due to their architecture, into three groups: plane structures (carbon rods), packed structures (granulated carbon) and brush structures $[88,89]$. Plane structures are often used in the laboratory and consist of carbon cloth/mesh/paper and graphite rods/blocks. Due to their excellent conductivity and chemical resistance, graphite rods are one of the most commonly used materials for the anode. The downside of this material is its limited surface area [88]. Carbon paper can also be difficult to use as it is thin and brittle, whereas roughened items such as carbon cloth/mesh are better due to their high surface area. Carbon mesh is also considerably less expensive than carbon cloth and generates a higher power density [89,90]. Activated carbon cloth removes more sulfide than other electrode materials due to its higher surface area and absorption capacity [91]. Graphite felt improves on both carbon cloth and mesh due to its thick but loose structure allowing for more bacterial adhesion due to the increased surface area [89]. Carbon fibre veils and papers have also been investigated as electrode materials and found to improve current generation by up to $40 \%$ compared to graphite rods, attributed to the increased surface area available for microbial biofilm [92-94]

Packed structures work to increase the surface area of the electrode, such as with granular graphite [89]. For the electrode to be properly conductive, the granular graphite must be packed tightly; however, 'dead zones' of current production can exist, along with clogging of the graphite, particularly after long-term running $[89,95,96]$.

Granulated activated carbon (GAC) has recently been studied as a potential anode material. It is inexpensive and provides a substantially increased surface area, which bacteria can adhere to [88]. GAC has also been used in composite electrodes together with multiple graphite rods in a single-chamber MFC (SCMFC) [97]. The GAC provides additional surface area for bacterial adhesion while the multiple graphite rods reduce the resistance of the MFC by the reduction of the distance for electron transfer within the GAC bed. The resultant GAC-SCMFC reached a maximum power density of $7.2 \mathrm{Wm}^{-3}$, several times higher than a standard two-chamber MFC (2CMFC) [97].

Building on the improvements of the packed structure for electrode development are brush structures. The use of brush structures as anodes was studies by Logan et al [95]. Brush electrodes consist of a highly conductive, non-corrosive metal core that is wrapped in graphite fibres. These are wound in an open structure to increase surface area and reduce fouling [95]. Another advantage of 
brush electrodes is their scalability. In comparison to other electrode materials, brush electrodes can be scaled up and have been used successfully in naval applications as cathodes in benthic MFCs $[2,95]$

\subsection{Other Materials}

Compounds other than carbon-based materials can be used for anode construction, with studies investigating the properties of other materials such as stainless steel, gold and titanium. However, these materials often provide a similar power outage to carbon and are considerably more expensive [88]. Other problems with metal electrodes include corrosion issues and the smooth surface that prevents bacterial adhesion [89]. Stainless steel, gold and titanium are the most commonly used metals. These types of electrodes work well in marine environments [98]. In this environment, a stainless steel cathode covered in a seawater biofilm was able to maintain $64 \mathrm{mWm}^{-2}$ and a current density of $1.89 \mathrm{Am}^{-2}$ [99]. Gold and titanium have also been used in a number of studies. Gold was found to be as effective an electrode as graphite by Richter et al [100]; however, uncoated titanium was found to be less effective [101]. In addition to other materials, surface treatments and coating are also used to improve electrode performance [89]. This can commonly include coating graphite in metals such as gold or palladium. This has the effect of increasing electrode performance over plain graphite [102].

Cathode construction also plays a part in power generation, and cathodes are often constructed from the same carbon-based materials as the anode. The difference is that the cathode needs to have a high redox potential, which can be improved by using catalysts such as platinum (Pt) or lead oxide $\left(\mathrm{PbO}_{2}\right)$ [88]. The expense of metals such as $\mathrm{Pt}$ limits the use of non-carbon cathodes.

\section{The Design and Application of MESs}

MESs have been extensively studied from a bioelectrochemical, microbiological and engineering perspective [103]. This has meant that, over time, MES platform designs have been refined, depending on their final application, in an endeavour to increase outputs and efficiency. This has resulted in a number of different MES architectures (Figure 3); however, MESs are divided into two main groups. Firstly, power-generating MFCs, which include two-chamber and single-chamber MFCs, and stacked MFCs; subsets of this group, relying on redox differentials within sediments, include benthic and sedimentary MFCs. Secondly, product/biofuel-producing MECs that include biofuel-producing MECs, chemical commodity producing MECs, and microbial desalination cells (MDCs), in addition to microbial solar cells (plant, algae and photosynthetic bacteria) capable of enhancing biofuel production in addition to generating biomass. Typically, an MES contains the same basic components: an anode and a cathode in separate chambers except in a single-chamber MFC (SCMFC) where the cathode is exposed to air, a proton exchange membrane (PEM), external load/resistance, a carbon source, electron donor and an electron acceptor $[15,104]$. This section details some of the most commonly used architectures and types of MESs used in both power-producing and product-producing applications. 


\section{Microbial fuel cells}

(a)

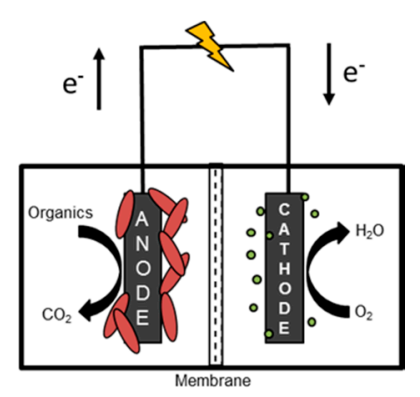

(b)

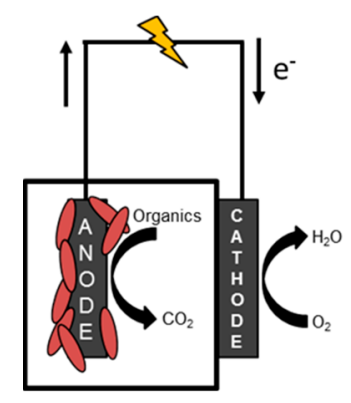

(c)

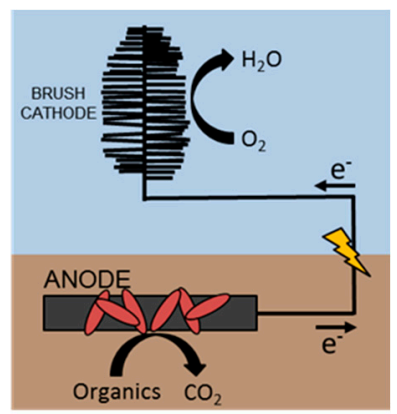

\section{Microbial biofuel cells}

(d)

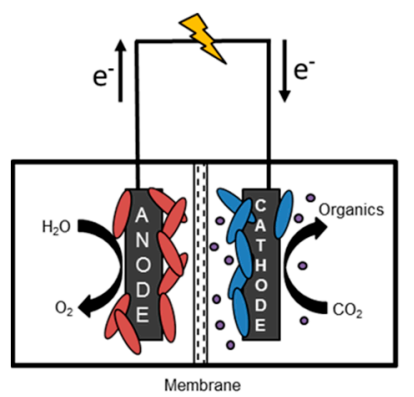

(e)

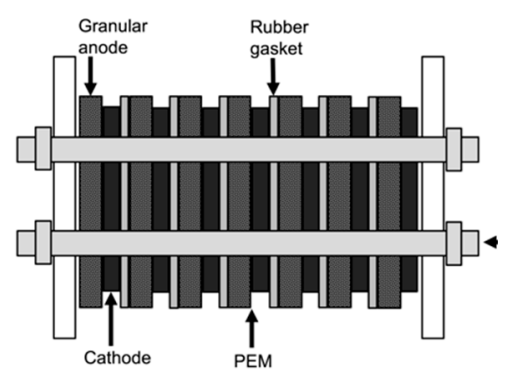

Microbial electrosynthesis cells

(f)

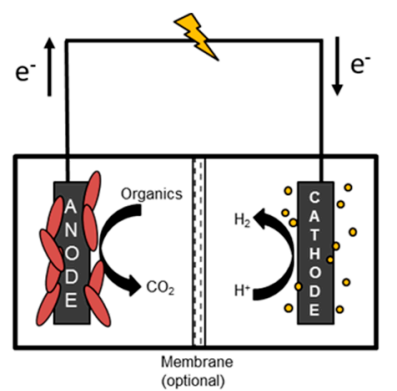

(g)

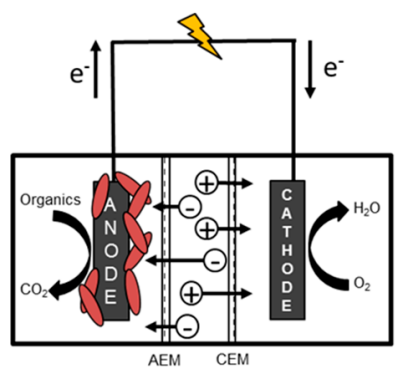

(h)

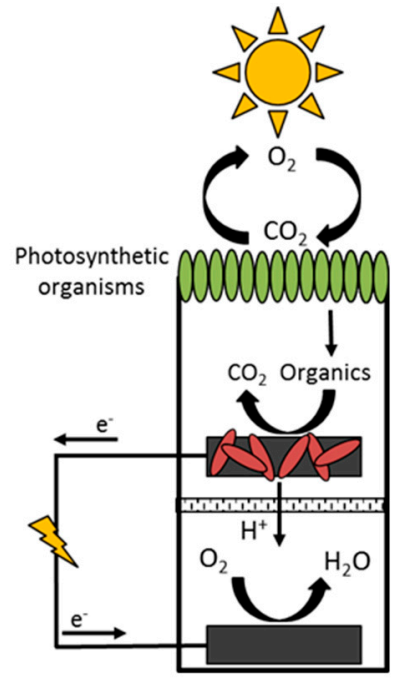

Figure 3. Schematic representations of different MES architectures. (a) Two-chamber microbial fuel cell, (b) single-chamber microbial fuel cell, (c) benthic or sediment microbial fuel cell, (d) microbial electrolysis cell, (e) stacked microbial fuel cell, (f) MEC synthesizing organic compounds, (g) desalination cell, (h) representative microbial solar cell. Images adapted from references $[1,2,15]$.

\subsection{MFCs for Power Production}

Traditionally, MFCs are used to generate power from the oxidation of organic matter by bacteria and the transfer of electrons from the anode to the cathode [105]. The classic H-style two-chamber 
MFC (2CMFC) is often the MFC design used in laboratory research and is similar to a standard electrochemical cell [15]. The basic configuration is of an anodic chamber separated from the cathodic chamber by a PEM. In this design, the microbes pass electrons obtained from the oxidation of the electron donor to the anode [106]. The electrons flow from the anode to the cathode, where they react with the protons that have passed into the cathodic chamber via the PEM and the electron acceptor (oxygen) to form water. To improve the power output of 2CMFCs, SCMFCs with air cathodes were developed which reduce the internal resistance of the MFC and the cost $[106,107]$. In these systems, the cathodic chamber is removed and the cathode is exposed directly to the air, with or without a membrane $[106,107]$. The membrane prevents oxygen diffusion into the anodic chamber as well as preventing water leakage to the cathode $[106,108]$. A further attempt to increase current output and substrate oxidation came with stacked MFCs, which evolved out of SCMFCs $[1,109,110]$. MFCs can be stacked either in series or parallel. When connected in series, the voltages of each MFC are added together and a common current flows through all [110]. However, if the MFCs are connected in parallel, the voltage is averaged and the currents are added. This flexibility allows the user to construct stacks that produce any desired current or voltage [110]. The standard set-up consists of the anode separated from the cathode by a PEM and separated from the next cell by a rubber gasket. Once the desired number of cells are added, the whole stack is bolted together $[15,110]$. One consideration of stacked systems is that the stack must be continuously fed with substrate as opposed to batch feeding $[110,111]$. This is to prevent fuel starvation in one of the cells of the stack. If this occurs and the microbial community dies, the overall voltage produced declines. So far, stacked systems show the most potential for miniaturisation and commercial up-scaling due to their ability to be connected in either series or parallel and their increased voltage production [111-113]. The efficiency of current generation in stacked MFC systems has also been successfully improved through the electrical reconfiguration of stacks between parallel and series to optimise voltage range [114]. Recent examples of stacked MFC systems have reached peak power densities of $50.9 \pm 1.7 \mathrm{~W} / \mathrm{m}^{3}$ and COD removal of $97 \%$, while stacked MEC systems for the refining of bioethanol have reached $91 \%$ efficiency of methane generation from waste products $[115,116]$.

\subsection{Benthic and Sedimentary MFCs for Power and Biofuel Production}

Reimers and Tender have been at the forefront of benthic MFC (BMFC) development $[13,14,31]$. Tender pioneered the development of benthic unattended generators (BUGs), which generate electricity from the microbial consumption of organic matter in aquatic sediments $[10,13,14]$. BMFCs are also known as sediment MFCs (SMFC) and their layout consists of an anode embedded into the sediment with the cathode suspended in the overlying water column [1]. Electrons from the oxidation of organics are transferred to the anode and pass onto the cathode where dissolved oxygen is reduced to water $[1,117]$. The abundance of organics in marine and other aquatic environments guarantees a continuous but low power output. This is advantageous when powering remote sensors and weather equipment, as there is no need to constantly replace batteries. In fact, Malik et al [118] estimated that it would take 22 years to consume all of the organics in $1 \mathrm{~L}$ of wet sediment $(6 \%$ organic matter), producing an average continuous current of $0.3 \mathrm{~mA}$, making SMFCs a promising alternative to battery-powered marine sensors [1]. In areas of low organic matter, SMFCs can be positioned in areas with high organic flux such as beneath fish farms, near wastewater treatment outlets and other nutrient-rich environments [2]. The use of BMFCs as an in situ restoration solution for the degradation of polycyclic aromatic hydrocarbons (PAH) has been demonstrated using sediments from riverbeds with up to 50\% removal of some PAHs over a 60-day period [119]. BMFCs present an ideal alternative power source compared to replaceable batteries for marine sensors such as magnetometers and acoustic sensors, with these systems having been operated for up to 6 months purely on BMFC-provided power [120,121]. 


\subsection{MECs for Biofuel Production and Chemical Synthesis}

Microbial electrolysis cells (MECs) incorporate electrotrophic microorganisms at the cathode, which utilise it as an electron donor. These microbes catalyse thermodynamically expensive electrolysis reactions so that the MEC can synthesize biofuels or commodity chemicals in an energetically favourable manner [5]. Some of the biofuels produced include hydrogen, methane, butanol and ethanol, and the commodity chemicals generated include glycerol, acetate and 2-oxobutyrate [4,5,20,122-124]. Currently known electrotrophs are Sporomusa ovata, Geobacter sulfurreducens, Clostridium ljungdahlii and Morella thermoacetica [4,122]. Microbial electrosynthesis (ME) technology utilised in MECs relies on these microbes to receive electrons from the cathode, which they subsequently use to reduce carbon dioxide and form useful chemical by-products such as biofuels and can also fix carbon, which is beneficial to reducing greenhouse gases [4,122].

As with MFCs, MECs have a variety of architectures, with the most common being two-chamber (2CMEC) and single-chamber (SCMEC) MECs. The main advantage of the 2CMEC system is its higher hydrogen production ability [20]. Methane yields of $80.9 \mathrm{~mL} / \mathrm{L}$ from 2CMEC systems have been reached in concert with the modification of the cathode with the addition of graphite felt to carbon rods to form a hybridised biocathode [125].

Although lower in hydrogen production, the membrane-free SCMECs are less costly than 2CMECs, particularly if hydrogen production can be improved by using continuous rather than batch mode operation. The application of membrane-free SCMECs in the fermentation of organic matter for energy recovery has resulted in improvements to the overall stability of anaerobic digestion processes while also improving the performance of energy recovery [126].

\subsection{Microbial Solar Cells Enhance MES Functions}

Microbial solar cells (MSCs) describe MESs that gain energy from photosynthesis by utilising plants (PMSCs), algae (AMSCs) or photosynthetic bacteria (BMSCs) in combination with electroactive bacteria $(\mathrm{EAB})$ to produce electrical current or commodity chemicals [1,16]. MSCs differ from other MECs in that they produce organics and carbon products via photosynthesis. These organics are then oxidised at the anode by the ARB before commodity chemicals are synthesised at the cathode via the reduction of oxygen or other final electron acceptors $[1,16]$. One advantage of using PMFCs over agricultural bioethanol or biodiesel production is that they do not use arable land that would be better allocated for food production [127]. In fact, competition between food production and energy generation has been circumvented in some rice paddy fields where electricity is generated and harvested via EAMs within the rice paddy without interrupting food production [128]. These systems potentially represent a dual benefit, as other studies have also shown that the addition of compost to PMFCs composed of rice plants has increased electricity production [129].

\subsection{Microbial Desalination Cells May Supplement Strategies for Water Sustainability}

It is estimated that, over the next few years, access to clean, potable water will continue to decrease, which will lead to a reliance on desalination technologies such as microbial desalination cells (MDCs) $[130,131]$. The main desalination technologies currently in use are distillation, electrodialysis and reverse osmosis, which can have high-energy demands. One way of improving the efficiency of the process is to use wastewater influent as a source of organics for EABs in MDCs. The EABs degrade the organic matter in the MDC to produce an electrical potential that drives ion transport through the ion exchange membrane (IEM), desalinating the water [131]. This provides 1.8 to $2.1 \mathrm{kWh} / \mathrm{m}^{3}$ of energy to the process, resulting in treated wastewater and desalinated sea water [131].

\subsection{Microbial Remediation Cells}

Another challenge throughout urban systems as well as developing nations is environmental contamination, including soil and groundwater contamination. Microbial remediation cells (MRCs) 
present a solution to such contamination, without the costly or energy-intensive methods currently in use [1]. MRCs act as MESs and are placed at sites of contamination to enrich and stimulate the activity of microorganisms, including EAMs, capable of degrading pollutants. MRCs set up for the degradation of diesel have demonstrated removal rates of up to $82 \%$ of contaminants [132]. The role of the electrode in MRCs varies based on the type of contaminant being targeted, with MRCs focused on petroleum or diesel utilising it as an acceptor [132,133], and those focused on the oxidation of uranium, perchlorate or chromium utilising the electrode as a donor [134-136].

\section{Conclusions and Future Prospects}

MESs have, in recent years, fuelled a range of investigators from different fields, including engineering, material sciences, and microbiology, to delve into the construction and application of these devices for the production of biocommodities including biofuels, as well as other applications such as the production of power or bioremediation of environments. These systems utilise the microbial metabolism of EAMs that can be harnessed with the presence of electrodes, which they can use to accept or donate electrons. EAMs that are capable of using electrodes as electron acceptors are known as electricigens and are capable of producing low amounts of electrical current in doing so. Furthermore, electrotrophs-EAMs that can use electrodes as electron donors-can be utilised for the production of compounds including biofuels and biogas. The understanding of the taxonomic range of EAMs, and the exact mechanisms used for EET, continue to expand, allowing for more opportunities to tailor the efficiency of EET mechanisms and the desired outcomes for different MES designs. Furthermore, by testing different materials and designs of the components within MESs, such as the anode, cathode and other membranes or filters, these devices continue to be specialised and improved for their individual aims. This review has outlined the basic components and designs of MECs, including MFCs for power generation and MECs for compound production, as well as the microbial taxa and EET mechanisms that are exploited within these systems.

Future prospects for research into MFCs should include further investigation into the feasibility of scaling-up differing MFC designs relative to their practical applications and the resulting material requirements, while continued investigation of the microbiological aspects of MFC operation both in the context of electricigens and eletrotrophs may further expand avenues for the optimisation of these devices through biological in addition to engineering-based approaches.

Author Contributions: Conceptualization, A.E.F., L.S., E.R.M. and G.D.; Writing-Original Draft Preparation, E.R.M. and G.D.; Writing-Review \& Editing, A.E.F., L.S., E.R.M. and G.D.; Visualization, E.R.M., L.S. and G.D.; Supervision, A.E.F.; Project Administration, A.E.F., L.S., E.R.M. and G.D.; Funding Acquisition, A.E.F. and E.R.M.

Funding: The authors E.R.M. \& G.D., acknowledges the financial support of an Australian Postgraduate Award at La Trobe University. The author E.R.M. acknowledges additional financial support from industry collaborators Western Water.

Conflicts of Interest: The authors declare no conflicts of interest.

\section{References}

1. Wang, H.; Ren, Z.J. A comprehensive review of microbial electrochemical systems as a platform technology. Biotechnol. Adv. 2013, 31, 1796-1807. [CrossRef] [PubMed]

2. Franks, A.E.; Nevin, K.P. Microbial fuel cells, a current review. Energies 2010, 3, 899-919. [CrossRef]

3. Khunjar, W.O.; Sahin, A.; West, A.C.; Chandran, K.; Banta, S. Biomass Production from Electricity Using Ammonia as an Electron Carrier in a Reverse Microbial Fuel Cell. PLoS ONE 2012, 7. [CrossRef] [PubMed]

4. Nevin, K.P.; Woodard, T.L.; Franks, A.E.; Summers, Z.M.; Lovley, D.R. Microbial Electrosynthesis: Feeding Microbial Electrosynthesis: Feeding Microbes Electricity to Convert Carbon Dioxide and Water to Multicarbon Extracellular Organic. mBio 2010, 1, e00103-10. [CrossRef] [PubMed]

5. Rabaey, K.; Rozendal, R.A. Microbial electrosynthesis-Revisiting the electrical route for microbial production. Nat. Rev. Microbiol. 2010, 8, 706-716. [CrossRef] [PubMed]

6. Lovley, D.R. Electromicrobiology. Annu. Rev. Microbiol. 2012, 66, 391-409. [CrossRef] [PubMed] 
7. Lovley, D.R.; Phillips, E.J. Novel mode of microbial energy metabolism: Organic carbon oxidation coupled to dissimilatory reduction of iron or manganese. Appl. Environ. Microbiol. 1988, 54, 1472-1480. [CrossRef] [PubMed]

8. Allen, R.M.; Bennetto, H.P. Microbial fuel cells: Electricity production from carbohydrates. Appl. Biochem. Biotechnol. 1993, 39, 27-40. [CrossRef]

9. Kim, B.H.; Kim, H.J.; Hyun, M.S.; Park, D.H. Direct electrode reaction of Fe(III)-reducing bacterium, Shewanella putrefaciens. J. Microbiol. Biotechnol. 1999, 9, 127-131.

10. Lovley, D.R. Bug juice: Harvesting electricity with microorganisms. Nat. Rev. Microbiol. 2006, 4, 497-508. [CrossRef] [PubMed]

11. Lovley, D.R. Microbial fuel cells: Novel microbial physiologies and engineering approaches. Curr. Opin. Biotechnol. 2006, 17, 327-332. [CrossRef] [PubMed]

12. Lovley, D.R. Powering microbes with electricity: Direct electron transfer from electrodes to microbes. Environ. Microbiol. Rep. 2011, 3, 27-35. [CrossRef] [PubMed]

13. Reimers, C.E.; Tender, L.M.; Fertig, S.; Wang, W. Harvesting energy from the marine sediment-water interface. Environ. Scie.Technol. 2001, 35, 192-195. [CrossRef]

14. Tender, L.M.; Reimers, C.E.; Stecher, H.A.; Holmes, D.E.; Bond, D.R.; Lowy, D.A.; Pilobello, K.; Fertig, S.J.; Lovley, D.R. Harnessing microbially generated power on the seafloor. Nature Biotechnol. 2002, 20, 821-825. [CrossRef] [PubMed]

15. Du, Z.; Li, H.; Gu, T. A state of the art review on microbial fuel cells: A promising technology for wastewater treatment and bioenergy. Biotechnol. Adv. 2007, 25, 464-482. [CrossRef] [PubMed]

16. Strik, D.P.B.T.B.; Timmers, R.A.; Helder, M.; Steinbusch, K.J.J.; Hamelers, H.V.M.; Buisman, C.J.N. Microbial solar cells: Applying photosynthetic and electrochemically active organisms. Trends Biotechnol. 2011, 29, 41-49. [CrossRef] [PubMed]

17. Rohrback, G.H.; Scott, W.R.; Canfield, J.H. Biochemical fuel cells. In Proceedings of the 16th Annual Power Sources Conference, Atlantic City, NJ, USA, 22-24 May 1962; Volume 18.

18. Fortman, J.L.; Chhabra, S.; Mukhopadhyay, A.; Chou, H.; Lee, T.S.; Steen, E.; Keasling, J.D. Biofuel alternatives to ethanol: Pumping the microbial well. Trends Biotechnol. 2008, 26, 375-381. [CrossRef] [PubMed]

19. Yan, Y.; Liao, J.C. Engineering metabolic systems for production of advanced fuels. J. Ind. Microbiol. Biotechnol. 2009, 36, 471-479. [CrossRef] [PubMed]

20. Zhou, M.; Wang, H.; Hassett, D.J.; Gu, T. Recent advances in microbial fuel cells (MFCs) and microbial electrolysis cells (MECs) for wastewater treatment, bioenergy and bioproducts. J. Chem. Technol. Biotechnol. 2013, 88, 508-518. [CrossRef]

21. Bajracharya, S.; Sharma, M.; Mohanakrishna, G.; Dominguez Benneton, X.; Strik, D.P.B.T.B.; Sarma, P.M.; Pant, D. An overview on emerging bioelectrochemical systems (BESs): Technology for sustainable electricity, waste remediation, resource recovery, chemical production and beyond. Renew. Energy 2016, 98, 153-170. [CrossRef]

22. Anderson, R.T.; Vrionis, H.A.; Ortiz-Bernad, I.; Resch, C.T.; Long, P.E.; Dayvault, R.; Karp, K.; Marutzky, S.; Metzler, D.R.; Peacock, A.; et al. Stimulating the In Situ Activity of Geobacter species to remove uranium from the groundwater of a uranium-contaminated aquifer. Appl. Environ. Microbiol. 2003, 69, 5884-5891. [CrossRef] [PubMed]

23. Williams, K.H.; Nevin, K.P.; Franks, A.; Englert, A.; Long, P.E.; Lovley, D.R. Electrode-based approach for monitoring in situ microbial activity during subsurface bioremediation. Environ. Sci. Technol. 2010, 44, 47-54. [CrossRef] [PubMed]

24. Lee, D.J.; Lee, C.; Chang, J.; Liao, Q.; Su, A. Treatment of Sulfate/Sulfide-Containing Wastewaters Using a Microbial Fuel Cell: Single and Two-Anode Systems. Int. J. Green Energy 2015, 12, 998-1004. [CrossRef]

25. Pikaar, I.; Rozendal, R.A.R.A.; Yuan, Z.; Keller, J.J.; Rabaey, K. Electrochemical sulfide removal from synthetic and real domestic wastewater at high current densities. Water Res. 2011, 45, 2281-2289. [CrossRef] [PubMed]

26. Rabaey, K.; Van de Sompel, K.; Maignien, L.; Boon, N.; Aelterman, P.; Clauwaert, P.; De Schamphelaire, L.; Pham, H.T.; Vermeulen, J.; Verhaege, M.; et al. Microbial Fuel Cells for Sulfide removal. Environ. Sci. Technol. 2006, 40, 5218-5224. [CrossRef] [PubMed]

27. Rohrback, G.H. Biological electrical power generation. U.S. Patent 3,228,799, 1 November 1966.

28. Davis, J.B.; Yarbrough, H.F. Biochemical fuel cell. U.S. Patent 3,331,705, 18 July 1967.

29. Angenent, L.; Zhen, H. Upflow microbial fuel cell (UMFC). U.C. Patent 20,060,147,763, 6 July 2006. 
30. Swift, J.A.; Butler, M.A.; Wallace, S.J. Microbial fuel cell and method. U.C. Patent 7,807,303, 5 October 2010.

31. Bond, D.R.; Holmes, D.E.; Tender, L.M.; Lovley, D.R. Electrode-reducing microorganisms that harvest energy from marine sediments. Science 2002, 295, 483-485. [CrossRef] [PubMed]

32. Bond, D.R.; Lovley, D.R. Electricity Production by Geobacter sulfurreducens Attached to Electrodes. Appl. Environ. Microbiol. 2003, 69, 1548-1555. [CrossRef] [PubMed]

33. Villano, M.; Aulenta, F.; Ciucci, C.; Ferri, T.; Giuliano, A.; Majone, M. Bioelectrochemical reduction of $\mathrm{CO}_{2}$ to $\mathrm{CH}_{4}$ via direct and indirect extracellular electron transfer by a hydrogenophilic methanogenic culture. Bioresour. Technol. 2010, 101, 3085-3090. [CrossRef] [PubMed]

34. RA, R.; AW, J.; HV, H.; CJ, B. Hydrogen production with a microbial biocathode. Environ. Sci. Technol. 2008, 42, 629-634.

35. Lovley, D.R.; Ueki, T.; Zhang, T.; Malvankar, N.S.; Shrestha, P.M.; Flanagan, K.A.; Aklujkar, M.; Butler, J.E.; Giloteaux, L.; Rotaru, A.E.; et al. Geobacter: The microbe electric's physiology, ecology, and practical applications. Adv. Microb. Physiol. 2011, 59, 1-100. [CrossRef] [PubMed]

36. Semenec, L.; Franks, A.E. The microbiology of microbial electrolysis cells. Microbiol. Aust. 2014, 35, $201-206$. [CrossRef]

37. Qiao, Y.; Qiao, Y.J.; Zou, L.; Ma, C.X.; Liu, J.H. Real-time monitoring of phenazines excretion in Pseudomonas aeruginosa microbial fuel cell anode using cavity microelectrodes. Bioresour. Technol. 2015, 198, 1-6. [CrossRef] [PubMed]

38. Bond, D.R.; Lovley, D.R. Evidence for Involvement of an Electron Shuttle in Electricity Generation by Geothrix fermentans Evidence for Involvement of an Electron Shuttle in Electricity Generation by Geothrix fermentans. Appl. Environ. Microbiol. 2005, 71, 2186-2189. [CrossRef] [PubMed]

39. Park, H.S.; Kim, B.H.; Kim, H.S.; Kim, H.J.; Kim, G.; Kim, M.; Chang, I.S.; Park, Y.K.; Chang, H.I. A novel electrochemically active and Fe(III)-reducing bacterium phylogenetically related to Clostridium butyricum isolated from a microbial fuel cell. Scanning 2001, 297-306. [CrossRef]

40. Angenent, L.T.; Karim, K.; Al-Dahhan, M.H.; Wrenn, B.A.; Domíguez-Espinosa, R. Production of bioenergy and biochemicals from industrial and agricultural wastewater. Trends Biotechnol. 2004, 22, 477-485. [CrossRef] [PubMed]

41. Holmes, D.E.; Bond, D.R.; Lovley, D.R. Electron Transfer by Desulfobulbus propionicus to Fe(III) and Graphite Electrodes. Appl. Environ. Microbiol. 2004, 70, 1234. [CrossRef] [PubMed]

42. Feng, C.; Li, J.; Qin, D.; Chen, L.; Zhao, F.; Chen, S.; Hu, H.; Yu, C.P. Characterization of exoelectrogenic bacteria enterobacter strains isolated from a microbial fuel cell exposed to copper shock load. PLoS ONE 2014, 9. [CrossRef] [PubMed]

43. Gregory, K.B.; Bond, D.R.; Lovley, D.R. Graphite electrodes as electron donors for anaerobic respiration. Environ. Microbiol. 2004, 6, 596-604. [CrossRef] [PubMed]

44. Gregory, K.B.; Lovley, D.R. Remediation and recovery of uranium from contaminated subsurface environments with electrodes. Environ. Sci. Technol. 2005, 39, 8943-8947. [CrossRef] [PubMed]

45. Dumas, C.; Basseguy, R.; Bergel, A. Microbial electrocatalysis with Geobacter sulfurreducens biofilm on stainless steel cathodes. Electrochim. Acta 2008, 53, 2494-2500. [CrossRef]

46. Lovley, D.R.; Nevin, K.P. Electrobiocommodities: Powering microbial production of fuels and commodity chemicals from carbon dioxide with electricity. Curr. Opin. Biotechnol. 2013, 24, 385-390. [CrossRef] [PubMed]

47. Roy, S.; Schievano, A.; Pant, D. Electro-stimulated microbial factory for value added product synthesis. Bioresour. Technol. 2015, 213, 129-139. [CrossRef] [PubMed]

48. Kumar, R.; Singh, L.; Zularisam, A.W. Exoelectrogens: Recent advances in molecular drivers involved in extracellular electron transfer and strategies used to improve it for microbial fuel cell applications. Renew. Sustain. Energy Rev. 2016, 56, 1322-1336. [CrossRef]

49. Zhang, Y.-C.; Jiang, Z.-H.; Liu, Y. Application of electrochemically active bacteria as anodic biocatalyst in microbial fuel cells. Chin. J. Anal. Chem. 2015, 43, 155-163. [CrossRef]

50. Inoue, K.; Leang, C.; Franks, A.E.; Woodard, T.L.; Nevin, K.P.; Lovley, D.R. Specific localization of the c-type cytochrome OmcZ at the anode surface in current-producing biofilms of Geobacter sulfurreducens. Environ. Microbiol. Rep. 2011, 3, 211-217. [CrossRef] [PubMed] 
51. Nevin, K.P.; Kim, B.C.; Glaven, R.H.; Johnson, J.P.; Woodward, T.L.; Methé, B.A.; Didonato, R.J.; Covalla, S.F.; Franks, A.E.; Liu, A.; et al. Anode biofilm transcriptomics reveals outer surface components essential for high density current production in Geobacter sulfurreducens fuel cells. PLoS ONE 2009, 4. [CrossRef] [PubMed]

52. Leang, C.; Qian, X.; Mester, T.; Lovley, D.R. Alignment of the c-type cytochrome OmcS along pili of Geobacter sulfurreducens. Appl. Environ. Microbiol. 2010, 76, 4080-4084. [CrossRef] [PubMed]

53. Qian, X.; Reguera, G.; Mester, T.; Lovley, D.R. Evidence that OmcB and OmpB of Geobacter sulfurreducens are outer membrane surface proteins. FEMS Microbiol. Lett. 2007, 277, 21-27. [CrossRef] [PubMed]

54. Mehta, T.; Coppi, M.V.; Childers, S.E.; Lovley, D.R. Outer membrane c-Type cytochromes required for Fe(III) and Mn (IV) oxide reduction in Geobacter sulfurreducens. Appl. Environ. Microbiol. 2005, 71, 8634-8641. [CrossRef] [PubMed]

55. Steidl, R.J.; Lampa-Pastirk, S.; Reguera, G. Mechanistic stratification in electroactive biofilms of Geobacter sulfurreducens mediated by pilus nanowires. Nat. Commun. 2017, 8, 15474. [CrossRef] [PubMed]

56. Reguera, G.; Nevin, K.P.; Nicoll, J.S.; Covalla, S.F.; Woodard, T.L.; Lovley, D.R. Biofilm and nanowire production leads to increased current in Geobacter sulfurreducens fuel cells. Appl. Environ. Microbiol. 2006, 72, 7345-7348. [CrossRef] [PubMed]

57. Malvankar, N.S.; Tuominen, M.T.; Lovley, D.R. Biofilm conductivity is a decisive variable for high-current-density Geobacter sulfurreducens microbial fuel cells. Energy Environ. Sci. 2012, 5, 5790. [CrossRef]

58. Liu, X.; Tremblay, P.L.; Malvankar, N.S.; Nevin, K.P.; Lovley, D.R.; Vargas, M. A Geobacter sulfurreducens strain expressing Pseudomonas aeruginosa type IV pili localizes OmcS on pili but is deficient in Fe(III) oxide reduction and current production. Appl. Environ. Microbiol. 2014, 80, 1219-1224. [CrossRef] [PubMed]

59. Malvankar, N.S.; Vargas, M.; Nevin, K.P.; Franks, A.E.; Leang, C.; Kim, B.-C.; Inoue, K.; Mester, T.; Covalla, S.F.; Johnson, J.P.; et al. Tunable metallic-like conductivity in microbial nanowire networks. Nat. Nanotechnol. 2011, 6, 573-579. [CrossRef] [PubMed]

60. Malvankar, N.S.; Vargas, M.; Nevin, K.; Tremblay, P.; Evans-lutterodt, K.; Nykypanchuk, D. Structural basis for metallic-like conductivity in microbial nanowires. mBio 2015, 6, 1-10. [CrossRef] [PubMed]

61. Malvankar, N.S.; Tuominen, M.T.; Lovley, D.R. Comment on “On electrical conductivity of microbial nanowires and biofilms" by S. M. Strycharz-Glaven, R. M.; Snider, A. Guiseppi-Elie and L. M. Tender, Energy Environ. Sci., 2011, 4, 4366. Energy Environ. Sci. 2012, 5, 6247-6249. [CrossRef]

62. Strycharz-Glaven, S.M.; Snider, R.M.; Guiseppi-Elie, A.; Tender, L.M. On the electrical conductivity of microbial nanowires and biofilms. Energy Environ. Sci. 2011, 4, 4366. [CrossRef]

63. Strycharz, S.M.; Tender, L.M. Reply to the 'comment on "On electrical conductivity of microbial nanowires and biofilms"' by N. S. Malvankar, M. T. Tuominen and D. R. Lovley, Energy Environ. Sci., 2012, 5, doi:10.1039/c2ee02613a. Energy Environ. Sci. 2012, 5, 6250-6255. [CrossRef]

64. Bond, D.R.; Strycharz-Glaven, S.M.; Tender, L.M.; Torres, C.I. On electron transport through geobacter biofilms. ChemSusChem 2012, 5, 1099-1105. [CrossRef] [PubMed]

65. Boesen, T.; Nielsen, P. Molecular dissection of bacterial nanowires. mBio 2013, 4, 3-5. [CrossRef] [PubMed]

66. Tan, Y.; Adhikari, R.Y.; Malvankar, N.S.; Ward, J.E.; Woodard, T.L.; Nevin, K.P.; Lovley, R. Expressing the Geobacter metallireducens PilA in Geobacter sulfurreducens Yields Pili with Exceptional Conductivity. mBio 2017, 8, 1-9. [CrossRef] [PubMed]

67. Pirbadian, S.; Barchinger, S.E.; Leung, K.M.; Byun, H.S.; Jangir, Y.; Bouhenni, R.A.; Reed, S.B.; Romine, M.F.; Saffarini, D.A.; Shi, L.; et al. Shewanella oneidensis MR-1 nanowires are outer membrane and periplasmic extensions of the extracellular electron transport components. Proc. Natl. Acad. Sci. USA 2014, 1-6. [CrossRef] [PubMed]

68. Pirbadian, S.; El-Naggar, M.Y. Multistep hopping and extracellular charge transfer in microbial redox chains. Phys. Chem. Chem. Phys. 2012, 14, 13802. [CrossRef] [PubMed]

69. Marsili, E.; Baron, D.B.; Shikhare, I.D.; Coursolle, D.; Gralnick, J.A.; Bond, D.R. Shewanella secretes flavins that mediate extracellular electron transfer. Proc. Natl. Acad. Sci. USA 2008, 105, 3968-3973. [CrossRef] [PubMed]

70. Daghio, M.; Gandolfi, I.; Bestetti, G.; Franzetti, A.; Guerrini, E.; Cristiani, P. Anodic and cathodic microbial communities in single chamber microbial fuel cells. New Biotechnol. 2015, 32, 79-84. [CrossRef] [PubMed] 
71. Rosenbaum, M.; Aulenta, F.; Villano, M.; Angenent, L.T. Cathodes as electron donors for microbial metabolism: Which extracellular electron transfer mechanisms are involved? Bioresour. Technol. 2011, 102, 324-333. [CrossRef] [PubMed]

72. Choi, O.; Sang, B.-I. Extracellular electron transfer from cathode to microbes: Application for biofuel production. Biotechnol. Biofuels 2016, 9, 11. [CrossRef] [PubMed]

73. Kumar, R.; Kumar, P. Future microbial applications for bioenergy production: A perspective. Front. Microbiol. 2017, 8, 1-4. [CrossRef] [PubMed]

74. Rotaru, A.E.; Shrestha, P.M.; Liu, F.; Ueki, T.; Nevin, K.; Summers, Z.M.; Lovley, D.R. Interspecies electron transfer via hydrogen and formate rather than direct electrical connections in cocultures of Pelobacter carbinolicus and Geobacter sulfurreducens. Appl. Environ. Microbiol. 2012, 78, 7645-7651. [CrossRef] [PubMed]

75. Sieber, J.R.; McInerney, M.J.; Gunsalus, R.P. Genomic Insights into Syntrophy: The Paradigm for Anaerobic Metabolic Cooperation. Annu. Rev. Microbiol. 2012, 66, 429-452. [CrossRef] [PubMed]

76. Summers, Z.M.; Fogarty, H.E.; Leang, C.; Franks, A.E.; Malvankar, N.S.; Lovley, D.R. Direct exchange of electrons within aggregates of an evolved syntrophic coculture of anaerobic bacteria. Science 2010, 330, 1413-1415. [CrossRef] [PubMed]

77. Shrestha, P.M.; Rotaru, A.E.; Aklujkar, M.; Liu, F.; Shrestha, M.; Summers, Z.M.; Malvankar, N.; Flores, D.C.; Lovley, D.R. Syntrophic growth with direct interspecies electron transfer as the primary mechanism for energy exchange. Environ. Microbiol. Rep. 2013, 5, 904-910. [CrossRef] [PubMed]

78. Rotaru, A.E.; Shrestha, P.M.; Liu, F.; Markovaite, B.; Chen, S.; Nevin, K.P.; Lovley, D.R. Direct interspecies electron transfer between Geobacter metallireducens and Methanosarcina barkeri. Appl. Environ. Microbiol. 2014, 80, 4599-4605. [CrossRef] [PubMed]

79. Semenec, L.; Laloo, A.E.; Schulz, B.L.; Vergara, I.A.; Bond, P.L.; Franks, A.E. Deciphering the electric code of Geobacter sulfurreducens in cocultures with Pseudomonas aeruginosa via SWATH-MS proteomics. Bioelectrochemistry 2017, 119, 150-160. [CrossRef] [PubMed]

80. Kato, S. Influence of Anode Potentials on Current Generation and Extracellular Electron Transfer Paths of Geobacter Species. Int. J. Mol. Sci. 2017, 18, 108. [CrossRef] [PubMed]

81. Commault, A.S.; Lear, G.; Weld, R.J. Maintenance of Geobacter-dominated biofilms in microbial fuel cells treating synthetic wastewater. Bioelectrochemistry 2015, 106, 150-158. [CrossRef] [PubMed]

82. Lovley, D.R. Happy together: Microbial communities that hook up to swap electrons. ISME J. 2017, 11, 327-336. [CrossRef] [PubMed]

83. Kim, Y.; Liesack, W. Differential assemblage of functional units in paddy soil microbiomes. PLoS ONE 2015, 10, e0122221. [CrossRef] [PubMed]

84. Hori, T.; Noll, M.; Igarashi, Y.; Friedrich, M.W.; Conrad, R. Identification of acetate-assimilating microorganisms under methanogenic conditions in anoxic rice field soil by comparative stable isotope probing of RNA. Appl. Environ. Microbiol. 2007, 73, 101-109. [CrossRef] [PubMed]

85. Chen, S.; Rotaru, A.-E.; Shrestha, P.M.; Malvankar, N.S.; Liu, F.; Fan, W.; Nevin, K.P.; Lovley, D.R. Promoting interspecies electron transfer with biochar. Sci. Rep. 2014, 4, 5019. [CrossRef] [PubMed]

86. Chen, S.; Rotaru, A.E.; Liu, F.; Philips, J.; Woodard, T.L.; Nevin, K.P.; Lovley, D.R. Carbon cloth stimulates direct interspecies electron transfer in syntrophic co-cultures. Bioresour. Technol. 2014, 173, 82-86. [CrossRef] [PubMed]

87. Li, L.L.; Tong, Z.H.; Fang, C.Y.; Chu, J.; Yu, H.Q. Response of anaerobic granular sludge to single-wall carbon nanotube exposure. Water Res. 2015, 70, 1-8. [CrossRef] [PubMed]

88. Zhou, M.; Chi, M.; Luo, J.; He, H.; Jin, T. An overview of electrode materials in microbial fuel cells. J. Power Sources 2011, 196, 4427-4435. [CrossRef]

89. Wei, J.; Liang, P.; Huang, X. Recent progress in electrodes for microbial fuel cells. Bioresour. Technol. 2011, 102, 9335-9344. [CrossRef] [PubMed]

90. Wang, X.; Cheng, S.; Feng, Y.; Merrill, M.D.; Saito, T.; Logan, B.E. Use of carbon mesh anodes and the effect of different pretreatment methods on power production in microbial fuel cells. Environ. Sci. Technol. 2009, 43, 6870-6874. [CrossRef] [PubMed]

91. Zhao, F.; Rahunen, N.; Varcoe, J.R.; Chandra, A.; Avignone-Rossa, C.; Thumser, A.E.; Slade, R.C.T. Activated carbon cloth as anode for sulfate removal in a microbial fuel cell. Environ. Sci. Technol. 2008, 42, 4971-4976. [CrossRef] [PubMed] 
92. Liu, Y.; Harnisch, F.; Fricke, K.; Schröder, U.; Climent, V.; Feliu, J.M. The study of electrochemically active microbial biofilms on different carbon-based anode materials in microbial fuel cells. Biosens. Bioelectron. 2010, 25, 2167-2171. [CrossRef] [PubMed]

93. Ieropoulos, I.; Greenman, J.; Melhuish, C. Microbial fuel cells based on carbon veil electrodes: Stack configuration and scalability. Int. J. Energy Res. 2008, 32, 1228-1240. [CrossRef]

94. Sonawane, J.M.; Yadav, A.; Ghosh, P.C.; Adeloju, S.B. Recent advances in the development and utilization of modern anode materials for high performance microbial fuel cells. Biosens. Bioelectron. 2017, 90, 558-576. [CrossRef] [PubMed]

95. Logan, B.; Cheng, S.; Watson, V.; Estadt, G. Graphite Fiber Brush Anodes for Increased Power Production in Air-Cathode Microbial Fuel Cells Graphite Fiber Brush Anodes for Increased Power Production in Air-Cathode Microbial Fuel Cells. Environ. Sci. Technol. 2007, 41, 3341-3346. [CrossRef] [PubMed]

96. Logan, B.E. Chapter 9: Materials for BES. In Bioelectrochemical Systems; Rabaey, K., Angenent, L.T., Schroder, U., Keller, J., Eds.; IWA Publishing: London, UK, 2010; p. 520. ISBN 9781843392330.

97. Jiang, D.; Li, B. Granular activated carbon single-chamber microbial fuel cells (GAC-SCMFCs): A design suitable for large-scale wastewater treatment processes. Biochem. Eng. J. 2009, 47, 31-37. [CrossRef]

98. Dumas, C.; Mollica, A.; Féron, D.; Basséguy, R.; Etcheverry, L.; Bergel, A. Marine microbial fuel cell: Use of stainless steel electrodes as anode and cathode materials. Electrochim. Acta 2007, 53, 468-473. [CrossRef]

99. Bergel, A.; Féron, D.; Mollica, A. Catalysis of oxygen reduction in PEM fuel cell by seawater biofilm. Electrochem. Commun. 2005, 7, 900-904. [CrossRef]

100. Richter, H.; McCarthy, K.; Nevin, K.P.; Johnson, J.P.; Rotello, V.M.; Lovley, D.R. Electricity Generation by Geobacter sulfurreducensAttached to Gold Electrodes. Langmuir 2008, 24, 4376-4379. [CrossRef] [PubMed]

101. Ter Heijne, A.; Hamelers, H.V.M.; Saakes, M.; Buisman, C.J.N. Performance of non-porous graphite and titanium-based anodes in microbial fuel cells. Electrochim. Acta 2008, 53, 5697-5703. [CrossRef]

102. Fan, Y.; Xu, S.; Schaller, R.; Jiao, J.; Chaplen, F.; Liu, H. Biosens. Bioelectron. Nanoparticle decorated anodes for enhanced current generation in microbial electrochemical cells. Biosens. Bioelectron. 2011, 26, 1908-1912. [CrossRef] [PubMed]

103. He, Z. Microbial Fuel Cells: Now Let us Talk about Energy. Environ. Sci. Technol. 2013, 47, 332-333. [CrossRef] [PubMed]

104. Khera, J.; Chandra, A. Microbial fuel cells: Recent trends. Proc. Natl. Acad. Sci. India Sect. A Phys. Sci. 2012, 82, 31-41. [CrossRef]

105. Janicek, A.; Fan, Y.; Liu, H. Design of microbial fuel cells for practical application: A review and analysis of scale-up studies. Biofuels 2014, 5, 79-92. [CrossRef]

106. Logan, B.E.; Hamelers, B.; Rozendal, R.; Schröder, U.; Keller, J.; Freguia, S.; Aelterman, P.; Verstraete, W.; Rabaey, K. Microbial fuel cells: Methodology and technology. Environ. Sci. Technol. 2006, 40, 5181-5192. [CrossRef] [PubMed]

107. Liu, H.; Logan, B.E. Electricity Generation Using an Air-Cathode Single Chamber Microbial Fuel Cell in the Presence and Absence of a Proton Exchange Membrane. Environ. Sci. Technol. 2004, 38, 4040-4046. [CrossRef] [PubMed]

108. Fan, Y.; Hu, H.; Liu, H. Enhanced Coulombic efficiency and power density of air-cathode microbial fuel cells with an improved cell configuration. J. Power Sources 2007, 171, 348-354. [CrossRef]

109. Rahimnejad, M.; Ghoreyshi, A.A.; Najafpour, G.D.; Younesi, H.; Shakeri, M. A novel microbial fuel cell stack for continuous production of clean energy. Int. J. Hydrogen Energy 2012, 37, 5992-6000. [CrossRef]

110. Aelterman, P.; Rabaey, K.; Pham, H.T.; Boon, N.; Verstraete, W. Continuous electricity generation at high voltages and currents using stacked microbial fuel cells. Environ. Sci. Technol. 2006, 40, 3388-3394. [CrossRef] [PubMed]

111. Oh, S.E.; Logan, B.E. Voltage reversal during microbial fuel cell stack operation. J. Power Sources 2007, 167, 11-17. [CrossRef]

112. Choi, S.; Chae, J. An array of microliter-sized microbial fuel cells generating 100 uw of power. Sens. Actuators A Phys. 2012, 177, 10-15. [CrossRef]

113. Boghani, H.C.; Papaharalabos, G.; Michie, I.; Fradler, K.R.; Dinsdale, R.M.; Guwy, A.J.; Ieropoulos, I.; Greenman, J.; Premier, G.C. Controlling for peak power extraction from microbial fuel cells can increase stack voltage and avoid cell reversal. J. Power Sources 2014, 269, 363-369. [CrossRef] 
114. Papaharalabos, G.; Greenman, J.; Stinchcombe, A.; Horsfield, I.; Melhuish, C.; Ieropoulos, I. Dynamic electrical reconfiguration for improved capacitor charging in microbial fuel cell stacks. J. Power Sources 2014, 272, 34-38. [CrossRef]

115. Wu, S.; Li, H.; Zhou, X.; Liang, P.; Zhang, X.; Jiang, Y.; Huang, X. A novel pilot-scale stacked microbial fuel cell for efficient electricity generation and wastewater treatment. Water Res. 2016, 98, 396-403. [CrossRef] [PubMed]

116. Sugnaux, M.; Happe, M.; Cachelin, C.P.; Gloriod, O.; Huguenin, G.; Blatter, M.; Fischer, F. Two stage bioethanol refining with multi litre stacked microbial fuel cell and microbial electrolysis cell. Bioresour. Technol. 2016, 221, 61-69. [CrossRef] [PubMed]

117. Donovan, C.; Dewan, A.; Heo, D.; Beyenal, H. Batteryless, wireless sensor powered by a sediment microbial fuel cell. Environ. Sci. Technol. 2008, 42, 8591-8596. [CrossRef] [PubMed]

118. Malik, S.; Drott, E.; Grisdela, P.; Lee, J.; Lee, C.; Lowy, D.A.; Gray, S.; Tender, L.M. A self-assembling self-repairing microbial photoelectrochemical solar cell. Energy Environ. Sci. 2009, 2, 292. [CrossRef]

119. Li, H.; Tian, Y.; Qu, Y.; Qiu, Y.; Liu, J.; Feng, Y. A Pilot-scale Benthic Microbial Electrochemical System (BMES) for Enhanced Organic Removal in Sediment Restoration. Sci. Rep. 2017, 7, 39802. [CrossRef] [PubMed]

120. Schrader, P.S.; Reimers, C.E.; Girguis, P.; Delaney, J.; Doolan, C.; Wolf, M.; Green, D. Independent benthic microbial fuel cells powering sensors and acoustic communications with the MARS underwater observatory. J. Atmos. Ocean. Technol. 2016, 33, 607-617. [CrossRef]

121. Arias-Thode, Y.M.; Hsu, L.; Anderson, G.; Babauta, J.; Fransham, R.; Obraztsova, A.; Tukeman, G.; Chadwick, D.B. Demonstration of the SeptiStrand benthic microbial fuel cell powering a magnetometer for ship detection. J. Power Sources 2017, 356, 419-429. [CrossRef]

122. Nevin, K.P.; Hensley, S.A.; Franks, A.E.; Summers, Z.M.; Ou, J.; Woodard, T.L.; Snoeyenbos-West, O.L.; Lovley, D.R. Electrosynthesis of organic compounds from carbon dioxide is catalyzed by a diversity of acetogenic microorganisms. Appl. Environ. Microbiol. 2011, 77, 2882-2886. [CrossRef] [PubMed]

123. Soussan, L.; Riess, J.; Erable, B.; Delia, M.L.; Bergel, A. Electrochemical reduction of $\mathrm{CO}_{2}$ catalysed by Geobacter sulfurreducens grown on polarized stainless steel cathodes. Electrochem. Commun. 2013, 28, 27-30. [CrossRef]

124. Villano, M.; Monaco, G.; Aulenta, F.; Majone, M. Electrochemically assisted methane production in a biofilm reactor. J. Power Sources 2011, 196, 9467-9472. [CrossRef]

125. Zhen, G.; Lu, X.; Kobayashi, T.; Kumar, G.; Xu, K. Promoted electromethanosynthesis in a two-chamber microbial electrolysis cells (MECs) containing a hybrid biocathode covered with graphite felt (GF). Chem. Eng. J. 2016, 284, 1146-1155. [CrossRef]

126. Zhen, G.; Kobayashi, T.; Lu, X.; Kumar, G.; Xu, K. Chemosphere Biomethane recovery from Egeria densa in a microbial electrolysis cell- assisted anaerobic system: Performance and stability assessment. Chemosphere 2016, 149, 121-129. [CrossRef] [PubMed]

127. Lu, L.; Xing, D.; Ren, Z.J. Microbial community structure accompanied with electricity production in a constructed wetland plant microbial fuel cell. Bioresour. Technol. 2015, 195, 115-121. [CrossRef] [PubMed]

128. Wetser, K.; Sudirjo, E.; Buisman, C.J.N.; Strik, D.P.B.T.B. Electricity generation by a plant microbial fuel cell with an integrated oxygen reducing biocathode. Appl. Energy 2015, 137, 151-157. [CrossRef]

129. Moqsud, M.A.; Yoshitake, J.; Bushra, Q.S.; Hyodo, M.; Omine, K.; Strik, D. Compost in plant microbial fuel cell for bioelectricity generation. Waste Manag. 2015, 36, 63-69. [CrossRef] [PubMed]

130. Cao, X.; Huang, X.; Liang, P.; Xiao, K.; Zhou, Y.; Zhang, X.; Logan, B.E. A New Method for Water Desalination Using Microbial Desalination Cells. Environ. Sci. Technol. 2009, 43, 7148-7152. [CrossRef] [PubMed]

131. Kim, Y.; Logan, B.E. Microbial desalination cells for energy production and desalination. Desalination 2013, 308, 122-130. [CrossRef]

132. Morris, J.M.; Jin, S.; Crimi, B.; Pruden, A. Microbial fuel cell in enhancing anaerobic biodegradation of diesel. Chem. Eng. J. 2009, 146, 161-167. [CrossRef]

133. Srikanth, S.; Kumar, M.; Singh, D.; Singh, M.P.; Das, B.P. Electro-biocatalytic treatment of petroleum refinery wastewater using microbial fuel cell (MFC) in continuous mode operation. Bioresour. Technol. 2016, 221, 70-77. [CrossRef] [PubMed]

134. Colantonio, N.; Kim, Y. Cadmium (II) removal mechanisms in microbial electrolysis cells. J. Hazard. Mater. 2016, 311, 134-141. [CrossRef] [PubMed] 
135. Shelobolina, E.S.; Vrionis, H.A.; Findlay, R.H.; Lovley, D.R. Geobacter uraniireducens sp. nov., isolated from subsurface sediment undergoing uranium bioremediation. Int. J. Syst. Evol. Microbiol. 2008, 58, 1075-1078. [CrossRef] [PubMed]

136. Lian, J.; Tian, X.; Li, Z.; Guo, J.; Guo, Y.; Yue, L.; Ping, J.; Duan, L. The effects of different electron donors and electron acceptors on perchlorate reduction and bioelectricity generation in a microbial fuel cell. Int. J. Hydrog. Energy 2017, 1-9. [CrossRef]

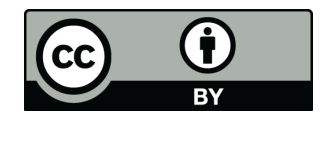

(C) 2018 by the authors. Licensee MDPI, Basel, Switzerland. This article is an open access article distributed under the terms and conditions of the Creative Commons Attribution (CC BY) license (http:/ / creativecommons.org/licenses/by/4.0/). 